\title{
A Collapsing Migratory Regime? The Map of the Migration Period and Its Iconology at the Beginning of the 21st Century
}

\begin{abstract}
For more than two centuries the "Barbarian" migrations into the Roman Empire that took place during the $4^{\text {th }}-6^{\text {th }}$ century CE have been remembered all over Europe in the form of eye-catching maps. Depending on the political climate, the "tribal arrows" that aim to indicate both the ethnicity and routes of late antique and early medieval immigrants have been arranged in very different iconological settings corresponding to very different political interpretations of the historic events. This essay argues that recently developed maps which present the Völkerwanderung as the collapse of a restrictive migratory regime are based on rather poor sources. Instead, other feasible strategies of depiction are discussed that might also satisfy the current desire for historical guidance (especially within the "Schengen" states), but without ignoring the current state of research.
\end{abstract}

Historical incidents or developments are frequently used as political arguments. Although every historian is familiar with this truism, concrete examples may indeed merit thorough consideration. Such is the case with the so-called migration period that in Western periodization separates antiquity and the middle ages. In the fall of 2015 the demographical processes which are usually labelled as the "Barbarian Invasions", the "Völkerwanderung" or the like ${ }^{1}$ became once again a crucially important element of political discourse. Faced with an abruptly rising tide of refugees, many Europeans believed their continent to be at the brink of a "new migration period", a mass immigration that not only fearful naysayers desperately hoped could be averted just in time. ${ }^{2}$ A few years later, such dire predictions have become a bit less dramatic. Anyhow, the transitions between collective memory and political debate are still flowing with respect to migration processes that took place about one and a half millennium ago. Because everywhere - from Iceland to Portugal, Italy or Turkey - the Eurasian migration patterns between the years 375 and 568 C.E. are more than just an integral part

1 See, for instance, Guy Halsall: Barbarian Migrations and the Roman West. Cambridge 2007, 376-568, here $10 f$.

2 Philipp Ther: Die Außenseiter. Flucht, Flüchtlinge und Integration im modernen Europa. Berlin 2017, esp. 285-287 and 305-308.

Ә Open Access. (C) 2018 Tillmann Lohse, published by De Gruyter. (c) BY-NC-ND This work is licensed under the Creative Commons Attribution-NonCommercial-NoDerivatives 4.0 License. 
of historical knowledge. The migration period is considered to be a "fact" that can provide a seemingly firm basis to scenarios of civilizational doom as well as to utopias of a borderless society.

For decades, cartographic illustrations have served as the main mnemonic code for the commemoration of the migration period. In 1801 the French navy lieutenant Emmanuel count de Las Cases published the original version of this type of map. ${ }^{3}$ His "Map, Exhibiting the Transmigration, Course, Establishment or Distruction [!] of the Barbarians that Invaded the Roman Empire" was designed so intelligibly that other cartographers immediately sought to adopt it in a more or less modified manner for their own historical atlases. Before 1900 such imitations appeared in France as well as in Germany, Russia, Portugal and Spain. During the 20th century they became truly omnipresent in nearly all states that today comprise the Council of Europe. Sooner or later the Völkerwanderung map à la Las Cases became an almost indispensable part of atlases and textbooks for the teaching of history. In Germany, Hungary or Sweden this happened already around 1930, in Great Britain and the Netherlands around 1960, and in most other countries sometime in between. ${ }^{4}$

Since their invention many layouts for the map of the migration period have been developed. Looking for the commonalities of the various designs one quickly realizes that all of them entail what Erwin Panofsky once called natural (or primary) and conventional (or secondary) subject matters. ${ }^{5}$ Essentially any Völkerwanderung map consists mainly of lines. In understanding these lines as pure forms, two kinds may be differentiated, namely delineating and connecting ones. Combined and arranged in a specific manner each kind of line triggers a certain concept or theme in the brain of the viewer, at least if he or she is familiar with the presupposed set of cultural codes: The linear contours represent Europe as a geographic entity. The linear connections mark the routes that late antique

3 A. Le Sage [pseudonym of Emmanuel de Las Cases]: Genealogical, chronological, historical, and geographical atlas. Exhibiting all the royal families in Europe, their origin, descendancy, mariages [!], etc. London 1801, no. 16. For the background of the mapper, see Walter Goffart: The Map of the Barbarian Invasions. A Preliminary Report, in: Nottingham Medieval Studies 32 (1988), 49-64, here 53-60.

4 Walter Goffart: The Map of the Barbarian Invasions. A Longer Look, in: Marc Anthony Meyer (ed.): The Culture of Christendom. Essays in Medieval History in Commemoration of Denis L. T. Bethell. London 1993, 1-27, esp. 16-21; Tillmann Lohse: Die Völkerwanderungskarte als europäischer Erinnerungsort. Ein Blick in die Geschichtsatlanten und -schulbücher des 18. bis 21. Jahrhunderts, in: idem and Benjamin Scheller (eds.): Europa in der Welt des Mittelalters. Ein Colloquium für und mit Michael Borgolte. Berlin 2014, 33-78 and 307-327, here 46-49.

5 Erwin Panofsky: Studies in Iconology. Humanistic Themes in the Art of the Renaissance. New York 1939, 4. 
and early medieval groups of people are supposed to have taken in the course of translocation.

But with this iconographic analysis, not much is gained for the historiographical interpretation of maps dealing with the migration period. To decipher the narratives conveyed by them, the maps have to be read iconologically, namely as "cultural symptoms". 6 A corresponding research paradigm was proposed by Panofsky some sixty years ago and has been widely debated and taken up since then. ${ }^{7}$ According to him one may find in every piece of art some "underlying principles which reveal the basic attitude" of the artist's social group "unconsciously [...] condensed into one work". And since such basic attitudes are inevitably related to political or ethical values, the varying natural and conventional subject matters of the maps under discussion may indicate quite different "intrinsic meanings or contents."

This essay does not aim to uncover all political agendas that during the last centuries have influenced the mapping of late antique and early medieval migrations. It rather focuses on maps that present this period as the collapse of a restrictive migratory regime. In the first section I will demonstrate that such examples, although hitherto rare, are quite a novel occurrence in the history of mapping the Völkerwanderung. Nevertheless, these maps draw on a long established iconological tradition whose historiographic argument they refine in a way that is both succinct and innovative. Since this "update" occurs as a result of current political developments, it is not very difficult to identify the "cultural symptoms" manifested in these maps. In contrast their scholarly evaluation is much more complicated, because in this case the historian is not merely challenged as a homo politicus, but also as a homo academicus. Consequently, in the second section I will discuss to what extent the core messages of maps envisaging the migration period as the collapse of a restrictive migratory regime correspond to the current state of historical research. The concluding third section shall be devoted to conceivable iconologies of late antique and early medieval migrations that might satisfy the current desire for historical guidance without ignoring the evidence of the preserved source material.

\section{Ibid., 16.}

7 Most recently by Jens Jäger: Überlegungen $\mathrm{zu}$ einer historiografischen Bildanalyse, in: Historische Zeitschrift 304 (2017), 655-682, here 659-661 (with further references). The historiography concerning historical atlases has elaborated quite ambitious research designs during the last decades. For my purpose, however, the rather simple methodological approach of Panofsky suffices.

8 Panofsky, Studies in Iconology, 7. 


\section{The Maps of the Migration Period and their "Cultural Symptoms"}

Much like other historiographical maps, ${ }^{9}$ those depicting the Völkerwanderung entail "cultural symptoms". These symptoms, however, are not always the same. Besides the common iconographic repertoire outlined above, the individual works usually contain further figurative elements that - one may hypothesize play a crucial role in shaping their respective iconologies. A survey ${ }^{10}$ of roughly 350 historical atlases from almost 40 European countries produced during the last two centuries shows a vast number of such additions: above all legends and dates, but also miniatures of Germanic warriors, Hunnic horsemen or Slavic peasants. ${ }^{11}$ Without question, all of these insertions carry a specific meaning. The best starting point for a comparative iconological analysis of the maps concerning the migration period is something else, though, namely the graphical division of the European landmass by means of coloring.

Admittedly, in different maps the areas that are distinguished from one another in such a way oscillate between state territories and settlement areas. But the manner in which spatial formation is depicted still allows a general distinction between two completely opposite interpretative patterns of the migration period that may be labelled as the "invasion narrative" on the one hand and the "colonization narrative" on the other.

While "invasion maps" present the Barbarian migrations as transgressions of Roman borders, "colonization maps" display them as a prehistory of the Germanic kingdoms established on Roman soil. The earliest cartographic elaborations of both such interpretations date back to the 1880s, when historical atlases became one of the most important learning media for teaching history at school. In the beginning the intrinsic meaning of these maps was not yet as readily apparent as in later times. This is because their erudite manufacturers

9 Cf., e.g., Patrick Lehn: Deutschlandbilder. Historische Schulatlanten zwischen 1871 und 1990. Ein Handbuch. Cologne 2008; Sylvia Schraut: Kartierte Nationalgeschichte. Geschichtsatlanten im internationalen Vergleich, 1860-1960. Frankfurt a. M. 2011.

10 Lohse, Völkerwanderungskarte, 63-78.

11 Atlas po stara i srednovekovna obšča istorija: Za peti i šesti klas. Sofija 1969, 12; Historia e mesjetës për klasën e VI të shkollës tetëvjeçare: harta. Tirana 1974, 1; Josip Lučić and Blagota Drašković: Povijesni atlas za osnovnu školu. 4th ed. Zagreb 1977, 8; Jean-Michel Lambin and Jean-Luc Carton: Atlas des collèges. Toutes les cartes des programmes d'histoire-géographie. Paris 2000, 15; Anabela Soares: Atlas histórico ilustrado. Porto 2002, 28. 
tended to conceal the message of their depictions in a veritable jumble of information. ${ }^{12}$ Later map designers knew how to avoid this mistake. ${ }^{13}$

In particular "colonization maps" quickly became popular with map makers. The rapid dissemination of this particular graphic rendition was facilitated by the fact that in most European countries - prior to the canonization of the tribal arrows of Las Cases - the standard repertoire of historical atlases already included a map showing the establishment of Germanic kingdoms in the early middle ages. ${ }^{14}$ Over time, three subtypes were developed, each of them based on simple, but highly effective iconographic accentuations: firstly, panoramic versions projected the modern European system of states - at least partially - back into early Middle Ages. ${ }^{15}$ Secondly, versions focusing just on a certain part of the continent depicted the mythical settlement of national forefathers. ${ }^{16}$ And thirdly, versions designed in the geopolitical mindset of Nazism were supposed to justify future conquests of the "Third Reich". ${ }^{17}$

As opposed to the impressive career of "colonization maps", the advance of “invasion maps" proceeded rather sluggishly. In the first part of the 20th century they can be found only in historical atlases of German or British provenience. ${ }^{18}$ Not until the second half of the century maps entitled "Barbarian invasions" did

12 An exemplary impression is given by Gustav Droysen and Richard Andree: Allgemeiner historischer Handatlas in sechsundneunzig Karten. Bielefeld 1886, 19.

13 Pathbreaking was Eduard Rothert: Historisches Kartenwerk 2: Karten und Skizzen aus der Geschichte des Mittelalters zur raschen und sichern Einprägung. Düsseldorf 1896, no. 3.

14 Lohse, Völkerwanderungskarte, 39, 42 and 47.

15 Presumably for the first time depicted by M. A. Denaix and Richard Wahl: Atlas physique, politique \& historique de l'Europe. Paris 1829, no. 13.

16 An early example is Juan de la Gloria Artero: Atlas histórico-geográfico de España, desde los tiempos primitivos hasta nuestros dias. Granada 1879, no. 7.

17 Even after 1939 most German mappers did not espouse such a mode of presentation. See Lohse, Völkerwanderungskarte, 50-52. Around 1950, however, a geopolitically minded map of the migration period was still published by Renate Riemeck and Hans Voigt: Kleiner Geschichtsatlas. Oldenburg [s.d.], 4. In his discussion of this map collection Lehn, Deutschlandbilder, 394-96, does not mention that Riemeck in 1941 became a member of the NSDAP. Regarding the bigger picture, cf. also Guntram H. Herb: Das größte Deutschland soll es sein! Suggestive Karten in der Weimarer Republik, in: Peter Haslinger and Vadim Oswalt (eds.): Kampf der Karten. Propaganda- und Geschichtskarten als politische Instrumente und Identitätstexte. Marburg 2012, 140-151 (with further references).

18 Eduard Rothert: 30 Karten zur deutschen Geschichte. 4th ed. Düsseldorf 1905, 3; Ernst Böttcher: Teubners Geschichtsatlas. Leipzig [ca. 1930], 8; James Francis Horrabin: An Atlas of European history from the 2nd to the 20th century. London 1935, no. 3. 
indeed depict Barbarian invasions. As would seem natural, maps of this type usually stemmed from countries with Romance languages. ${ }^{19}$ The first attempts to advance substantially the iconology of "invasion maps", though, came from Soviet scholars. Following their Marxist philosophy of history, Evgenij A. Kosminskij and Anatolij P. Levandovskij were not content with simply mapping the Barbarian incursions. In a map, published in 1951, they marked with red dots those areas, in which they determined revolutionary uprisings of slaves, peasants and miners to have taken place. ${ }^{20}$ Subsequently, this cartographic concept of representing the migration period as the breakdown of a society of slaveholders was frequently adopted across Socialist states, until by 1989 the last of these depictions disappeared from historical atlases. ${ }^{21}$

Towards the end of the twentieth century, a second subtype of the "invasion map" emerged. Its most systematic iteration so far appeared with a map entitled "La pressione dei barbari durante la crisi del terzo secolo" (Fig. 1), which was published in 1997 by Marco Drago and Andrea Boroli in their "Nuovo atlante storico".22 In comparison to traditional versions some specific iconographic additions can be observed that strikingly affect the iconology of the map. In the drawing of the two Italian map designers the Roman border is not just a line that migrants cross in the course of their translocation. It is a bulwark, or more precisely: a bulwark that was devised to, but proved unable to prevent, this very crossing.

Two additional graphical elements bring about the visual transformation of the Roman border line into such a bulwark. Since both elements are not yet conventional cartographical symbols, the map-makers explain them in the legend. Massive black squares (24 altogether) are supposed to represent those legions of soldiers who were detailed particularly for border management, and jagged lines (13 altogether) are meant to symbolize the buildings that were erected especially for border security. Overall, the map's depiction leaves no doubt concerning the true effect of the Roman border control: merely one barrier far from the actual border is able to stop the migration of the Gepids. Nineteen other tribes, however, easily continue on their chosen paths. And it is by no means only Germanic tribes that brave the restrictive migration regime of the

19 See, e.g., Sebastiano Crinò: Atlante storico, vol. 2: Evo medio e moderno. 6th ed. Milan 1960, 6, map C ("Schizzo itinerario delle principali invasion barbariche”); J. Vicens Vives: Atlas de historia de universal. Barcelona ${ }^{16} 1980$ [first edition 1954], no. 17 (“Las invasiones germánicas”); António do Carmo Reis: Atlas de história de Portugal. Porto ${ }^{2} 1987$, no. 12 (“As Invasões Bárbaras”).

20 Evgenij A. Kosminskij and Anatolij P. Levandovskij: Atlas istorii srednich vekov. Moscow 1951, 1f.

21 Lohse, Völkerwanderungskarte, 52f.

22 Marco Drago and Andrea Boroli, Nuove atlante storico. Novara 1997, no. 17/I. 


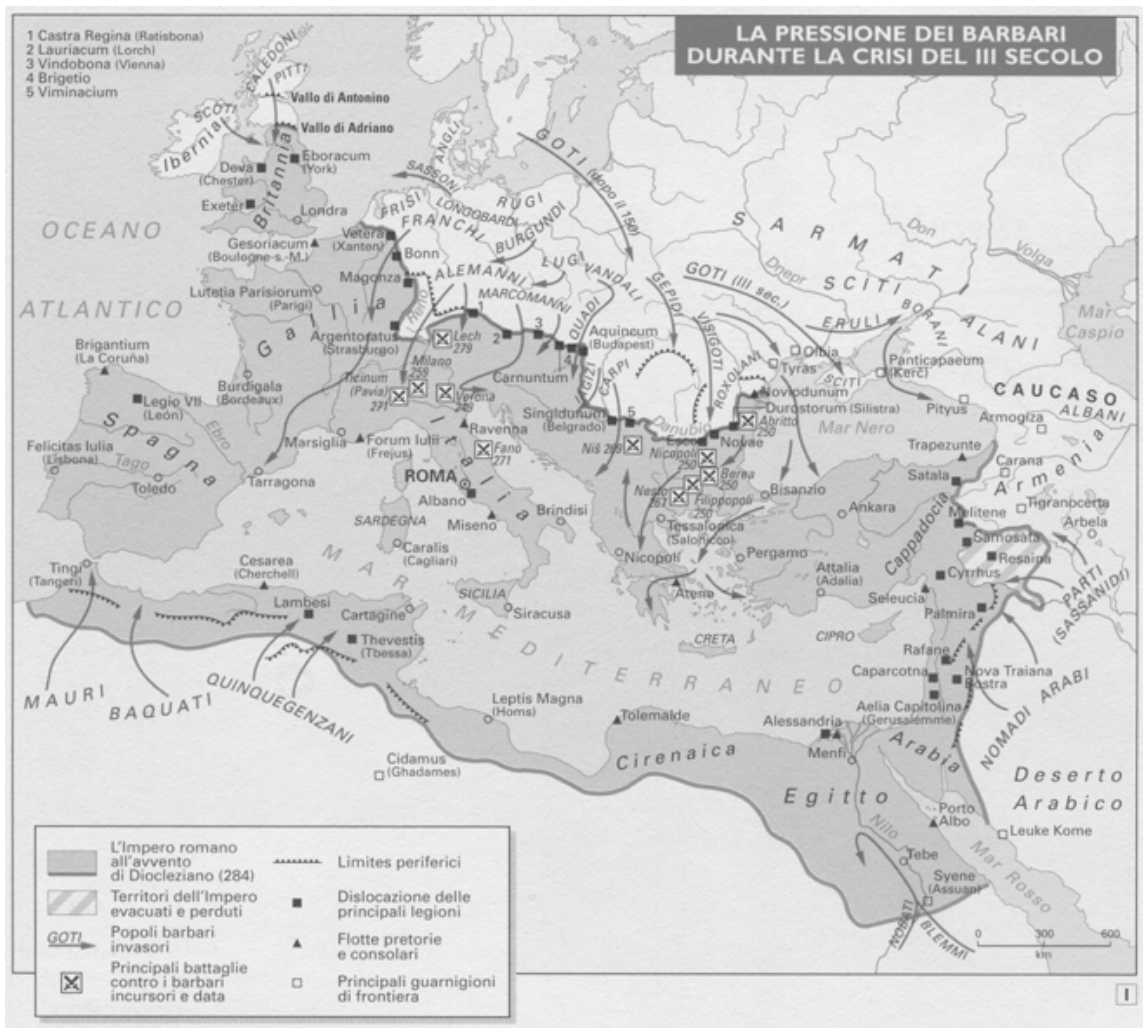

Fig. 1: "The Barbarian immigration pressure during the crisis of the 3rd century" (from an Italian historical atlas of 1997)

Romans: in the East Parthians as well as Arabs and in the South Nubians, Blemmyes and Berbers find their way into the empire.

The idea to map the migration period as the story of a failing immigration control does not originate with Drago and Boroli. The two Italians just developed the most expressive iconography for such an interpretative presentation so far. They were likely inspired by a Völkerwanderung map that was published under the directorship of George Duby a few years earlier: The "Atlas historique Larousse", initially published in 1978 and reprinted in 1992, already contained a map dealing with the problem of migration control by means of border fortifications (Fig. 2). ${ }^{23}$ In

23 Georges Duby (dir.): Atlas historique Larousse. Paris 1978 [repr. ibid. 1992], 30. Previously the Upper Germanic-Rhaetian Limes had been already depicted by Dimitŭr Konśtantinov (Atlas po bŭlgarska istorija. Sofia 1963, 5f.), but without shaping the map's general impression. Later on, a slightly stronger accentuation of the Roman border fortifications appeared in another Bulgarian 


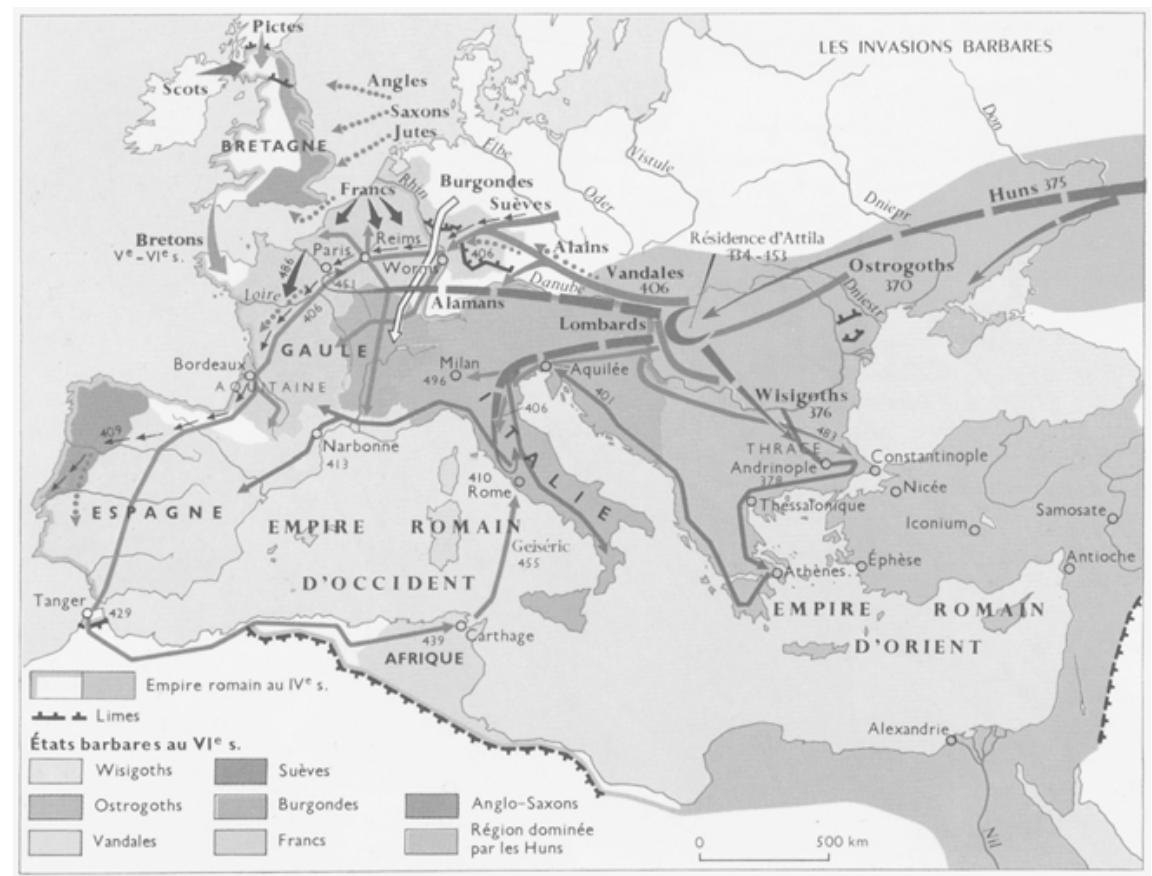

Fig. 2: "The Barbarian invasions" (from a French historical atlas of 1978)

fact, its border fortifications (limites) are drawn even more distinctly than in the Italian example, but as a whole the message remains less suggestive. In the French drawing, too, barriers nowhere ever are able to stop men and women who wish to translocate: The Picts smoothly surmount the Antonine Wall, as do the Suebians, Alans, Vandals and Burgundians cross the Upper Germanic-Rhaetian Limes. Furthermore, the colored highlighting of the Barbarian successor states, which as a rule appears to be very untypical for "invasion maps", emphasizes the collapse of the Roman migratory regime. But due to the extraordinary complex (and diachronic) design the general statement of the map appears more blurred than with the one by Drago and Boroli.

Despite some small discrepancies, the migration period maps stemming from the "Nuovo atlante storico" and the "Atlas historique Larousse" obviously bear the same "cultural symptoms": Both of them give the impression that in the early

map of the migration period that might have been the inspiration for the French mappers. See Atlas po stara i srednovekovna obšča istorija. Za peti i šesti klas. Sofia 1969, 12. 
middle ages there were some people who tried to hinder the translocation of other people - but did so unsuccessfully! And both maps relate this observation to the Roman limites, the remnants of which are today considered world heritage sites.

With the adopting and elaborating design of the Völkerwanderung map that highlights border facilities as a means of immigration control, Drago and Boroli, wether intentionally or not, reacted to the gradual opening of the intra-European borders, which from the outset was connected directly to the protection of the common external border. The call for a joint migration policy of the so-called Schengen countries created a new awareness for the value of state migratory regimes and the instruments of their enforcement.

A close intellectual connection between the establishment of the European Union's external border and the presentation of limites within maps of the migration period can also be observed on the basis of two younger adaptations from Eastern Europe: The map entitled "Didysis tautu kraustymasis" (= "The Great Migration of People") published by Albinas Pilipaitis and Petras Gaučas in $2004^{24}$ and the map entitled "Wędrówka ludów - Podział i upadek imperium rzymskiego" (= "The Wandering of People - Division and Fall of the Roman Empire") published by Jacek Gawrysiak in 2008. ${ }^{25}$ Both works were created during the period when Lithuania and Poland became full member states of the Schengen Area.

Iconographically these younger versions closely follow the map published by Larousse. The Polish one, however, does so less directly than the Lithuanian one, because in the former map the immigrating Barbarians do not cross the border fortifications (as they do in the French template), but bypass them (Fig. 3). ${ }^{26}$ At first glance this might appear to be an insignificant detail, but regarding the iconology of the map it is vitally important. For tribal arrows passing border facilities suggest that the restrictive migratory regime of the Romans collapsed, even though it utilizes walls; whereas tribal arrows circumventing border facilities insinuate that the restrictive migratory regime of the Romans collapsed, because the walls erected for its enforcement did not sufficiently and comprehensively fence off the external border.

24 Albinas Pilipaitis and Petras Gaučas: Visuotinès istorijos atlasas mokykloms. Vilnius 2004, 14. This map was reproduced by Ojārs Bušs et al.: Vēstures Atlants skolām. Riga 2009 (without pagination).

25 Jacek Gawrysiak: Atlas Historyczny. Od starożytności do wspótczesności - Liceum. Warsaw 2008, 17. A simplified version was published one year later: Jacek Gawrysiak: Atlas Historyczny. Od starożytności do wspótczesności - Szkoła Podstawowa. Warsaw 2009, 15.

26 According to the depiction only the Huns were able to cross the limites. Contrary to the German tribes, however, they were no immigrants, but just raiders. 


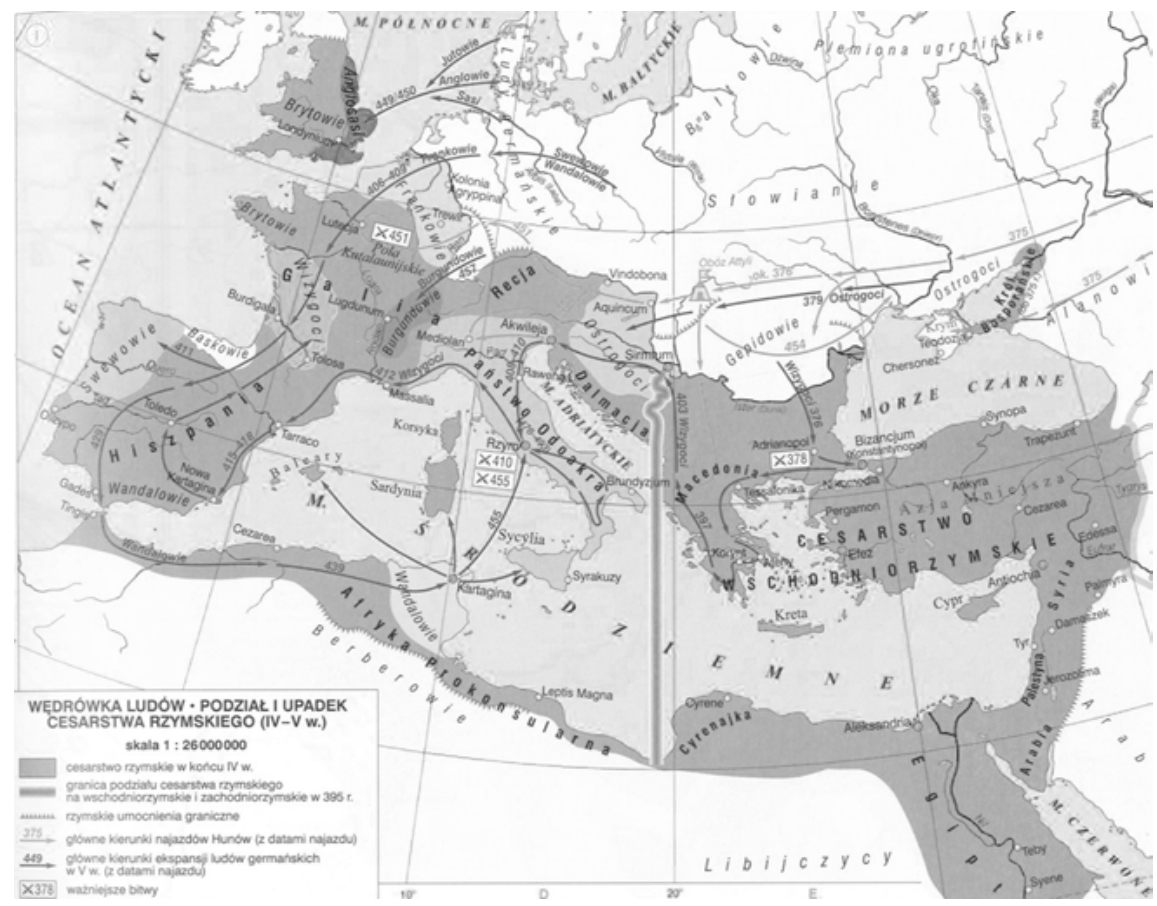

Fig. 3: "The Wandering of People - Division and Fall of the Roman Empire" (from a Polish atlas of 2008)

Thus, at the core we are dealing with two competing historiographical claims that could very well be read as statements on the present and future migration policy of the Schengen countries. Whether scholars and mappers of late antiquity and the early middle ages should volunteer as political advisors at all, is a matter of opinion. But since maps such as the ones discussed above shape the historical awareness of future generations responsible historians cannot evade the following question: To what degree do such iconologies correspond with established historical knowledge based on latest research? With that, I will turn to the second section of my argument.

\section{Some Scholarly Advice: Beware of Völkerwanderung Maps!}

Völkerwanderung maps in the tradition of Las Cases have long been the subject of fierce criticism. At least since the 1960s international scholarship has deemed 
such drawings as largely unscientific. The ancient historian Gerold Walser, for instance, stated that the optimism of earlier researchers to reconstruct the tribal migration paths by combining the findings of archaeology and historical linguistics were "long gone". ${ }^{27}$ By contrast he observed that most of the historical atlases still did not demonstrate adequate restraint. Instead their mappers drew tribal history with rough lines across Eurasia and thus relapsed into the romantic notion that the migrating groups of persons were unchangeable ethnic entities.

The de-essentialization of the Barbarian tribes or peoples still preoccupies current research. In the last decade or so this methodological problem has probably been dealt with more consistently than ever before. For instance, it has been recently argued that there definitely was no "migratory avalanche" of the Lombards in $568 \mathrm{CE}$. What medieval historians just a generation ago imagined as a single, almost 100 kilometers-long trek of ethnically homogenous emigrants, ${ }^{28}$ is now considered to have been a chain migration of very heterogenous small groups that dragged on for several decades. ${ }^{29}$ Even more, by current migration researchers stress unanimously that translocations are a constitutive part of the conditio humana, just as birth, procreation and death. In the words of the British historian Peter Heather: "It is an inescapable conclusion from all the comparative literature, that a basic behavioural trait of Homo sapiens sapiens is constantly to use (...) migration (...) as a strategy for maximizing quality of life, not least for gaining access to richer food supplies and all other forms of wealth." 30 If, however, migration is considered to have been not an exceptional, but rather the everyday mode of societies, and if men and women across time - individually or in groups - have been moving their residence, then there is no longer any real reason to single out one singular "migration period" from the historical continuum and to present it in a discrete map.

27 Gerold Walser: Zu den Ursachen der Reichskrise im dritten nachchristlichen Jahrhundert, in: Schweizer Beiträge zur Allgemeinen Geschichte 18/19 (1960/61), 142-161, here 151f.

28 Jörg Jarnut: Die Landnahme der Langobarden in Italien aus historischer Sicht, in: Michael Müller-Wille and Reinhard Schneider (eds.): Ausgewählte Probleme europäischer Landnahmen des Früh- und Hochmittelalters. Methodische Grundlagendiskussionen im Grenzbereich zwischen Archäologie und Geschichte. Sigmaringen 1993, vol. 1, 173-194, here 182.

29 Michael Borgolte: A Migration Avalanche of Lombards in 568? A Critique of Historiographic Evidence of the Migration Period, in: Leidulf Melve and Sigbjørn Sønnesyn (eds.): The Creation of Medieval Northern Europe. Christianisation, Social Transformation, and Historiography. Essays in Honour of Sverre Bagge. Oslo 2012, 119-138.

30 Peter Heather: Empires and Barbarians. The Fall of Rome and the Birth of Europe. Oxford 2012, 579. 
In sum, scholarly criticism regarding the Völkerwanderung maps may be subsumed under two objections: improper essentialization of tribes/peoples on the one hand and improper "epochalization" of the late antique and early medieval migrations on the other hand. A few years ago, the medieval historian Bernhard Jussen referring to both of these problems drew an obvious conclusion and unequivocally demanded: "Abolish all maps of the migration period!"31

Many historians may sympathize with this appeal, because Jussen is definitely correct in saying that the great population movements during the 4th-6th centuries did not take place as the map's arrows suggest, that they were not that targeted, nor that compact - not even approximately so. ${ }^{32}$ But in its decisiveness Jussen's demand might fall short. Three issues I would like to take into consideration:

First, one should not underestimate to what extent the map of the migration period has been engrained into the pictorial memory of Europeans over the last decades. At the beginning of the 21st century it belongs, as shown above, to the commonly shared illustrative arsenal of historical imagination, in which political views and basic attitudes of European societies tend to "sediment". ${ }^{33}$ Academic historians simply may not have the means to erase the map from public memory.

Second, by bemoaning the "serious harm" Völkerwanderung maps do "to public historical imagination" 34 a rather indiscriminating perception of the picture is assumed. On the sole ground that the initial contact with such maps usually takes place during history lessons in school, the images are not merely passively received. In other words, the cartographical image and the picture act

31 Bernhard Jussen: Die Franken. Geschichte, Gesellschaft, Kultur. Munich 2014, 17: "Schluss mit den Völkerwanderungskarten!”

32 Ibid., 17f.: "Die großen Bevölkerungsbewegungen verliefen nicht so, wie die Pfeile der Karten es suggerieren - nicht so zielgerichtet, nicht so kompakt, ja, nicht einmal so ähnlich.”

33 Bernhard Jussen: Bilderhorizonte. Wege zu einer Ikonologie nationaler Rechtfertigungsnarrative, in: Andreas Fahrmeir and Annette Imhausen (eds.): Die Vielfalt normativer Ordnungen. Konflikte und Dynamik in historischer und ethnologischer Perspektive. Frankfurt a. M. 2013, 79-107, here 82: "Politische Vorstellungen und Grundorientierungen einer Kultur sind sedimentiert in mehr oder weniger kanonisierten Reservoirs historischer Bebilderungen.” With due regard to historical atlases, see additionally Vadim Oswalt: Die Macht der Visualisierung historischer Räume - Atlanten der Weltgeschichte als Medium der Geschichtskultur in Europa, in: Saskia Handro and Bernd Schönemann (eds.): Raum und Sinn. Die räumliche Dimension der Geschichtskultur. Berlin 2014, 195-210.

34 Jussen, Franken, 17: "Diese Karten (...) haben viel Unheil in der historischen Imagination angerichtet." 
(Bildakt) do not necessarily coincide. ${ }^{35}$ More than just a few history teachers may actually encourage their pupils to scrutinize the iconology of historical maps. And even where such basic rules of historical learning are disregarded, an uncritical reception cannot be taken for granted. In popular culture, the German movie "Die Feuerzangenbowle" (1944) and the French comic "Astérix et les Goths" (1963), for example, have caricatured the map and its application in school for good reason. ${ }^{36}$

Third, to eliminate maps of the migration period would mean to needlessly waste an opportunity to inform public debate. During the last two centuries generations of historians have used the mapping concept originally created by Emmanuelle de Las Cases to focus their understanding of late antique and early medieval migrations into a consistent iconology. If today's scholars try to evade this challenge, they risk ceding the interpretation to others.

\section{Alternative Approaches?}

Any in-depth survey of maps showing late antique and early medieval migrations that date from the last two decades leads to very sobering results. Completely unimpressed by the scholarly critique, most historical atlases still repeat schemes of depiction dating back to the first part of the 20th century. The maps of Drago/Boroli, Pilipaitis/Gaučas and Gawrysiak seem to be the only ones that discernibly relate the historical plot to the present situation. By focusing on the migratory regime of the Roman Empire, these also pick up questions that are currently a topic of intensified discussion amongst historians and archaeologists. And yet, maps like the ones just mentioned may - at most - be a stimulation, not a model for an iconology that satisfies both the current desire for historical guidance and the evidence of the preserved source material. Two questions will suffice here to address the latter: Did the Romans really practice a restrictive migratory regime? And, were the limites actually their weapon of choice to enforce such a policy?

To make such a wide-ranging claim like the collapse of a restrictive migratory regime during late antique and early medieval times definitely requires more supporting evidence than a single reference to the "Historia Augusta"

35 Concisely, for instance, Gerhard Paul: Von der historischen Bildkunde zur Visual History. Eine Einführung, in: Idem (ed.): Visual History. Ein Studienbuch. Göttingen 2006, 7-36, here 18. 36 Lohse, Völkerwanderung, 56-58. 
(written around $400 \mathrm{CE}$ ), which reports that emperor Hadrian (died in $138 \mathrm{CE}$ ) had ordered the construction of a wall, eighty miles in length, that was supposed "to separate Barbarians and Romans." ${ }^{37}$ Leading specialists of Roman border facilities, at any rate, suggest interpretations that point into a completely different direction. According to Egon Schallmeyer, for instance, the limites in the individual provinces were not heavily armed border systems, as the older literature has supposed, but rather a "line of encounter". According to him, the main purpose of the new border facilities was "to focus the border traffic on single, particularly monitored gateways." 38 Should not today's historical atlases reflect research findings like these? All it would take to graphically transform the limites from an instrument of blockade and exclusion into an instrument for canalizing flows of people and goods would be some minor retouches. But, as a matter of course, the insertion of gateways to limites depictions by itself will not be sufficient to create an iconology consistent with the current state of research. In particular it has to be stressed, that the Roman border system based on limites already broke down during the second half of the 3rd century CE. ${ }^{39}$ Its depiction in any map dealing with later periods, therefore, is simply anachronistic.

Furthermore, the ethnic coding of migration arrows belongs into the dustbin of history! The coloring of arrows should no longer signal ethnic homogeneity of the migrants or the wholesale translocation of "entire" peoples, but instead reference the character of the respective migrations. A military conquest, for example, has to be denoted in other ways than, say, the recruiting of soldiers or the accommodation of refugees. Similarly, ad hoc relocations caused by war or expulsion should be displayed in different ways than step-by-step resettlements as a result of chain migrations. All raids that did not aim at any permanent translocation, by contrast, should be omitted completely. Migration paths such as those taken by the Vandals, which are stored in the pictorial memory of the Europeans as a single, almost circular route going from the

37 Spartiani De Vita Hadriani,XI.2, ed. Ernst Hohl et al. (Bibliotheca scriptorum Graecorum et Romanorum Teubneriana). Leipzig 1971, 13: "murumque per octoginta milia passuum primus duxit, qui barbaros Romanosque divideret”. See Wolfgang Moschek: Der römische Limes. Eine Kultur- und Mentalitätsgeschichte. Speyer 2011, $79 f$.

38 Egon Schallmayer: Der Limes. Geschichte einer Grenze. Munich 3rd edition 2011, 10: “[Der Limes stellte] kein waffenstarrendes und undurchdringliches Grenzsystem dar, wie noch die ältere Forschung vermutet hat (...), sondern eine 'Linie der Begegnung." Ibid., 92: "Zweck der neuen Grenz- einrichtung war es, (...) den Grenzverkehr auf einzelne, besonders überwachte Durchgänge zu lenken." See also Eckart Olshausen et al.: Limes, in: Brill's New Pauly. URL: http://referenceworks.brillonline.com/entries/brill-s-new-pauly/limes-e705510 (20th Dec. 2017).

39 Wolfgang Moschek: Der Limes. Grenze des Imperium Romanum. Darmstadt 2010, $106 \mathrm{f}$. 
upper reaches of river Elbe to Rome or Sardinia, need to be segmented into several stages of different nature whose last one would definitely be located in Northern Africa. ${ }^{40}$

In addition, mappers should heed that all types of migration include remigration in some way or other. This phenomenon is well known from broadly documented examples of modern times; its absence during the middle ages seems not plausible at all. ${ }^{41}$ Paul the Deacon (died 799), for instance, claims the Lombards had abandoned their dwelling places in Pannonia to the Avars only on the condition that they, if needed, would be allowed to return. ${ }^{42}$ For an improved iconology of Völkerwanderung maps this means that the migration arrows should cross the borderline of the Roman Empire not only at specified gateways, but also in two directions. And if arrows are meant to represent historically accurate migration paths instead of mythographical references back to a putative original homeland, their future mapping will require much more geographical precision. ${ }^{43}$ Frequently, such reconstructions will have to contend with the sparse data provided by the narrative sources. It's hardly a stretch, however, to assume that outside the empire Barbarians travelled longer distances mainly on rivers, whereas inside the empire they used well-paved roads.

Finally, the coloring of areas needs some modification as well. Much will be gained, if the iconography of the maps differentiates more thoroughly between state territories and settlement areas, with a special focus on interrelations and not accordance. In this way it would be possible to show that with both Romans and Barbarians the two spaces were not necessarily congruent. Völkerwanderung maps that focus heavily on limites as "lines of encounter" may also benefit from marking completely different areas. This could be, for instance, so-called archeological cultures - i.e. the spatial distributions of typologically "equal” artifacts,

40 Cf. already Walter Goffart: What's Wrong with the Map of the Barbarian Invasions?, in: Susan J. Ridyard and Robert G. Benson (eds.): Minorities and Barbarians in Medieval Life and Thought. Sewanee 1996, 159-177, here 162f. and 174f.

41 Heather, Empires, 30 and 592f.

42 Pauli Historia Langobardorum II.7, ed. Georg Waitz (Monumenta Germaniae Historica. Scriptores rerum Germanicarum in usum scholarum separatim editi). Hannover 1878, 89.

43 The earliest attempt of such a mapping strategy dates back to the 18th century. See Johann Georg Hagelgans: Atlas historicus, Oder allgemeine historische Charten, Darinnen die merckwürdigste Begebenheiten, so sich von Anfang der Welt in allen Königreichen und Landen biss auff unsere Zeit geäussert, abgebildet (...). Frankfurt a. M. 1718. URL: <http://diglib.hab.de/ drucke/gb-gr-2f-3/start.htm> (20 Dec.2017). 
whose ethnic interpretability nowadays is claimed just by very few specialists ${ }^{44}$ or even genomic mappings based on DNA traces from early medieval cemeteries. ${ }^{45}$

Admittedly, this is quite an extensive wish-list. Most notable, however, is not its length, but the fact that no mapper would be able to implement even a single one of these wishes at short notice. Why? Because historians have failed to do the preliminary work, due to their pronounced distaste for Völkerwanderung maps which became so widespread in the profession roughly two generations ago. Thus, the design of a sophisticated map addressing migration patterns during late antiquity and the early middle ages is by no means just a problem of "cartographic ethics". ${ }^{46}$

44 Sebastian Brather: Ethnizität und Mittelalterarchäologie. Eine Antwort auf Florin Curta, in: Zeitschrift für Archäologie des Mittelalters 39 (2011), 161-172; Manuel Fernández-Götz: Ethnische Interpretation und archäologische Forschung: Entwicklung, Probleme, Lösungsansätze, in: TÜVA Mitteilungen 14 (2013), 59-76.

45 Patrick J. Geary and Krishna Veeramah: Mapping European Population Movement through Genomic Research, in: Medieval Worlds 4 (2016), 65-78.

46 Cf. John B. Harley: Can there be a Cartographic Ethics?, in: idem: The New Nature of Maps. Essays in the History of Cartography. Paul Laxon (ed.). Baltimore 2001, 197-207, here 204. 